\title{
The Effect of Democratic Leadership Style on the Performance of Employees at PT. Medan Industry Area (Persero)
}

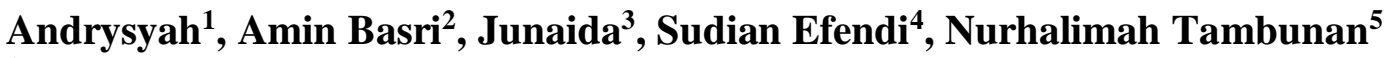 \\ ${ }^{1,5}$ Politeknik LP3I Medan \\ ${ }^{2}$ Universitas Muhammadiyah Sumatera Utara \\ ${ }^{3}$ STIT Al Ittihadiyah Labura \\ ${ }^{4}$ SMA Swasta Nurul Islam Indonesia \\ andrysyah29@gmail.com,aminbasri@umsu.ac.id, aidajunaida26@gmail.com,dianchanshu@gmail.com, \\ nurhalimahtambunan2406@gmail.com
}

\begin{abstract}
The objective of this research were to determine the effect of democratic leadership style on performance of employees at PT. Medan Industry Area (Persero). The purpose of this research was to determine how the influence of democratic leadership style on performance of employees at PT. Medan Industry Area (Persero) ". Sources of data in this research are employees of PT. Medan Industry Area (Persero), with a population and a sample of 40 people (Respondents). The data was collected using a questionnaire and dating analysis using the SPSS 25 application. And the data collected using a questionnaire will then be tested for validity, reliability test, $f$ test, and test the coefficient of determination. The results of this research indicate that the determination coefficient test $(R 2)$ in table 4:23 shows that the magnitude of the influence of the democratic leadership style is 0.069, this means that the democratic leadership style has an influence on employee performance. Thus it can be concluded that this indicates that the democratic leadership style is very good. And in the F test table 4.22 below, the value of Fcount > Ftable, the value of Fcount can be seen at the percentage point of the $f$ test. Then the independent variable $(X)$ (independent), namely leadership style (3.908>4.09), has a significant effect on employee performance (dependent). Thus it can be concluded that with the influence of democratic leadership styles on employee performance, employees will be increasingly motivated to be able to provide good and maximum work results, and will direct all their abilities to improve performance, so they will be able to complete their tasks properly. And with the resulting Adjusted $R$ Square value of $6.9 \%$ the effect and the rest is influenced by other variables.
\end{abstract}

Keywords

leadership, democratic leadership style; performance of employees

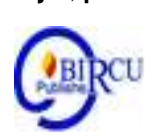

\section{Introduction}

Leadership is a practical skill that includes the ability of a person or organization to lead or guide other people, teams, organizations, and companies. Leadership is a very important factor in influencing and providing direction to employees, what's more when the system is open, it is a leadership figure that strengthens employees. The Leadership Style is a method or pattern and certain abilities used by a leader in understanding, communicating and being able to influence, direct, encourage and control other people or subordinates in order to do a job so as to achieve a goal. The success that is obtained from an organization or organization whose performance has been determined, and carry out it with the responsibilities that have been given. 
Based on the research of Kadek Ary Setiawan (2016) in his research "The Effect of Leadership Style and Compensation on Employee Performance of PT. Astra Honda Nusa Dua Bandung Regency" explains that the purpose of his research is the influence of leadership style and compensation on employee performance. This shows that the leadership style has a positive and significant effect on employee performance. And shows that the statement of leadership style, the employee's performance will increase significantly. The difference between this study and previous research is that it lies in the influence of leadership style and compensation on employee performance in this study to determine the effect of leadership style on employee performance, that in the author's study, the author wanted to know about the influence of leadership styles possessed by company leaders.

PT. Medan Industry Area (Persero) is a State-Owned Enterprise (BUMN) with the business of industrial estate management services. This area was established on October 7 , 1998, with a composition of shares consisting of the Government of Indonesia (central) 60\%, North Sumatra Provincial Government 30\%, and Medan City Government 10\%, always well planned by management. The leadership style possessed by the main director of PT. Medan Industry Area (Persero) is a democratic leadership style so that leaders often include employees in decision making and employees can work together and prioritize work quality, but not all employees feel the leadership style possessed by company leaders, some of them always feel excessive fear when following company leaders they often assume too much with company leaders, they assume when they consider leaders their company is making a mistake at work.

\subsection{Formulation of the Research}

The formulation of the problem in this study is "how the influence of democratic leadership style on employee performance at PT. Medan Industry Area (Persero)"

\subsection{Limitation of the Research}

The limitation of this problem is only on the influence of democratic leadership style on employee performance at PT. Medan Industry Area (Persero) in the recording period from March to July 2020.

\subsection{Objectives of the Research}

The purpose of this study was to determine how the influence of democratic leadership style on employee performance at PT. Medan Industry Area (Persero).

\subsection{Benefits of the Research}

This research can add knowledge to the author and an understanding of democratic leadership and its application to human resource management where it has been studied in college and in the real world of work. 


\section{Review of Literatures}

Hasibuan (2009: 170) Defining leadership is a way for a leader to influence the behavior of his subordinates so that they are willing to work together and work productively to achieve organizational goals.

Sudriamunawar (2017) Democratic leadership style is a leadership style known as participative style. This style assumes that subordinates who take part personally in the decision-making process are more likely to have a result of having a greater commitment to organizational goals and objectives. follows:

Mahendro Sumarjo (2018) the characteristics of a democratic leadership style are as

a. The workload of the organization is the joint responsibility of the human resources in the organization.

b. Employees are considered as the main component in the implementation of work so that the strategic role of employees needs to be adjusted to the duties and responsibilities they carry.

c. The leader still plays a dominant role but is not rigid in solving problems together.

d. High trust in employees by not releasing supervisory responsibilities.

e. Communication with employees is open and communicative.

Dessler (2014) Employee performance is work performance, namely the comparison between work results that are seen in real terms with work standards that have been set by the organization.

Simamora (2007) Performance is the level of employee work results in achieving the requirements of a given job.

Bernadine (2014) Employee performance indicators are as follows:

a. Quality

The degree to which the results of the activities carried out are nearly perfect, in the sense of adjusting some ideal way of performing activities or fulfilling the expected goals of an activity.

b. Quantity

The amount generated in terms of the number of units, the number of activity cycles completed.

c. Timeliness

The level of an activity is completed at the desired initial time, seen from the point of view of coordination with the output results and maximizing the time available for other activities.

d. Effectiveness

The level of use of the organization's human resources is maximized with the intention of increasing the profits or reducing the losses of each unit in the use of resources.

e. Independence

The degrees to which an employee can perform his job function without asking for guidance from the supervisor or asking the supervisor to intervene in order to avoid adverse results.

According to Robbins and Judge (2008), leaders are who inspire their followers to put aside their personal interests for the good of the organization and are able to have an extraordinary influence on their followers. According to Yukl (2010), transformational leadership is a situation where the followers of a transformational leader feel trust, admiration, loyalty and respect for the leader, and they are motivated to do more than they initially expected. 
Leadership can be defined as a process of directing and giving influence to the activities of a group of members who are related to their duties (Stoner, 1992: 114). According to Gorton et al., Leadership is a characteristic of leaders in influencing subordinates to achieve organizational goals. The success of leadership is partly determined by the ability of leaders to develop their organizational culture. (Arif, 2019).

Leadership is very important for the development of every human activity and in general for the whole social environment. As a phenomenon, leadership is a key for success of companies, so it plays great attention both in theory and in practice. Leaders who are able to encourage, change and use values, beliefs and needs of their followers' execution of tasks in crisis situations and dynamic major changes are transformational leaders. (Griffin $\mathrm{R}$ in Fauza, 2020). Organization always strives to create a good working relationship between leaders and subordinates, in maintaining this condition a leader who can exert influence and can foster a work ethic of subordinates at work, so that his performance is more leverage. In the application of leadership communication, leaders can communicate with various types of leadership communication in accordance with the selection of communication patterns. The type of leadership communication must be owned by a leader for the leader to use in influencing his subordinates to achieve organizational goals. (Dailami et al, 2002)

During life, humans are never separated from leadership, even the most independent modern people still need leaders (Sudibjo in Purba, 2020). The quality of leadership contained in an organization plays a very dominant role in the success of the organization in carrying out its various activities, especially seen in the performance of its employees According to Robbins (2010), if a leader succeeds in influencing subordinates with his vision, instilling his charisma, motivating and being an inspiration, stimulating intellectual, creativity and respecting his employees can be sure that employees will work well, seriously and loyal to the company so that their performance increases. (Siagian in Purba, 2020)

The term performance or work performance comes from the English word "performance". According to Busro in Purba (2020), performance is defined as work ability in terms of quality and quantity. Performance is a work performance (performance) both in quantity and quality achieved by someone during a certain period, usually within one year. According to Ivancevich, Konopaske and Matteson (Busro, 2018) that performance shows the ability and skills of workers. Opinions emphasize the competence of human resources possessed by organizations, ranging from the ability of employees' cognition, affection, and psychomotor.

\section{Research Methods}

The data of analysis method in this research was quantitative method. The quantitative method according to Sugiyono (2016), which can be interpreted as a research method based on the philosophy of positivism, is used to research on certain populations or samples, data collection uses research instruments, data analysis is quantitative or statistical, with the aim of testing predetermined hypotheses. By explaining and explaining the data obtained from the questionnaire data distributed to employees of PT. Medan Industry Area (Persero). Then the data were analyzed based on statistical tests using SPSS. 


\section{Discussion}

The author conducted of this research with the quantitative descriptive method, namely by giving questionnaires to employees of PT. Medan Industry Area (Persero) which is located at Jl. Batam Island No. 1, Sempali, Kec. Percut Sei Tuan Kab. Deli Serdang, North Sumatra. with the number of respondents as many as 40 people. The questionnaire made by the writer consisted of 18 statements, in which there were 2 variables, where the $X$ variable consisted of 8 statements and the $\mathrm{Y}$ variable consisted of 10 statements. The characteristics of the respondents are the identities of the employees sampled by the authors. From the description of the characteristics that the author got at PT. Medan Industry Area (Persero).

Table 1. Characteristics of respondents based on gender

\begin{tabular}{clcc}
\hline No & Gender & $\begin{array}{l}\text { Number of } \\
\text { people }\end{array}$ & Percentage (\%) \\
\hline 1 & Man & 19 & 47,5 \\
2 & Women & 21 & 52,5 \\
& Total & 40 & 100 \\
\hline
\end{tabular}

Source: Processed data (2020)

Based on table 1, it can be seen that the number of respondents based on male gender is 19 people or $47.5 \%$ of respondents and based on female gender with a total of 21 or $52.5 \%$ of respondents. Who is an employee at PT. Medan Industry Area (Persero) which is the object of the author's research.

Table 2. Characteristics of respondents based on division

\begin{tabular}{|c|c|c|c|}
\hline N0 & Division & $\begin{array}{l}\text { Number of } \\
\text { people }\end{array}$ & Percentage $\%$ \\
\hline 1 & SDM & 4 & 10 \\
\hline 2 & Public & 4 & 10 \\
\hline 3 & Sales \& Marketing & 4 & 10 \\
\hline 4 & Financial & 4 & 10 \\
\hline 5 & BP3S & 3 & 7,5 \\
\hline 6 & PKBL & 3 & 7,5 \\
\hline 7 & $\begin{array}{l}\text { System and } \\
\text { obedience }\end{array}$ & 3 & 7,5 \\
\hline 8 & $\begin{array}{l}\text { Production \& } \\
\text { Operation }\end{array}$ & 3 & 7,5 \\
\hline 9 & infrastructure & 3 & 7,5 \\
\hline 10 & Corporate Secretary & 5 & 12,5 \\
\hline 11 & $\begin{array}{l}\text { Internal Control } \\
\text { System }\end{array}$ & 4 & 10 \\
\hline & Total & 40 & 100 \\
\hline
\end{tabular}

Source: Processed data (2020) 
Based on table 2, it can be seen that the respondents based on the HR division are 4 people or $10 \%$ of respondents, based on the General division there are 4 people or $10 \%$ of respondents, based on the Sales \& Marketing division there are 4 people or $10 \%$ of respondents, based on the Finance division there are 4 people or $10 \%$ of respondents, based on the BP3S division there were 3 people or $7.5 \%$ of respondents, based on the PKBL division there were 3 people or $7.5 \%$ of respondents, based on the System and Compliance division there were 3 people or $7.5 \%$ of respondents, based on the Production \& Operations division there were 3 people or $7.5 \%$ of respondents, based on the Infrastructure division there were 3 people or $7.5 \%$ of respondents, based on the Corporate Secretary division there were 5 people or $12.5 \%$ of respondents, and based on the Internal Control System there were 4 people or $10 \%$. Who is an employee at PT. Medan Industry Area (Persero) which is the object of the author's research.

The results that the authors obtained from the results of this study were conducted through distributing questionnaires to employees of PT. PT. Medan Industry Area (Persero) with 40 respondents. This research was conducted to determine the influence of democratic leadership style on employee performance. This study uses 2 variables, namely variables $X$ and $\mathrm{Y}$, the number of statements 18 on the democratic leadership style variable $(\mathrm{X})$ and the employee performance variable (Y) which will be used as a benchmark in making the questionnaire. Based on the research conducted, the author will discuss the Effect of Democratic Leadership Style on Employee Performance.

And based on the research that the author did get the results from the coefficient of determination (R2) it can be seen that the magnitude of the influence of the democratic leadership style is 0.069 , this means that the democratic leadership style has an influence on employee performance. Thus it can be concluded that this indicates that the democratic leadership style is very good. So it can be concluded that the results of previous research with the research that the authors did were equally significant.

\section{Conclusion}

The conclusion from the observations there is a high influence between the influence of democratic leadership style on employee performance at PT. Medan Industry Area (Persero). Evidenced by the results of the F test from data processing, the value of Fcount is 3,908 and Ftable is 4.09 after comparing the value of Fcount > Ftable and based on the significant value is 0.000 which is smaller than 0.05. From this analysis, then Ho is rejected, meaning that there are simultaneous variables of Democratic Leadership Style affecting Employee Performance variables. From all the conclusions above, it can be concluded that the Democratic Leadership Style is influenced by Employee Performance at PT. Medan Industry Area (Persero). 


\section{References}

Arif, S. (2019). Influence of Leadership, Organizational Culture, Work Motivation, and Job Satisfaction of Performance Principles of Senior High School in Medan City. Budapest International Research and Critics Institute-Journal (BIRCI-Journal). P. 239-254

Dailami, et al. (2020). The Communication Patterns of Leadership in Improving Work Ethic of Lecturer and Staff in Asahan University (Islamic Communication Perspective). Budapest International Research and Critics Institute-Journal (BIRCI-Journal). P. 469476.

Fauza, M. (2020). The Correlation between Transformational Leadership Styles with Teacher's Performance in SMP Negeri 2 Medan. Budapest International Research and Critics in Linguistics and Education (BirLE) Journal. P. 1164-1169.

Feriyanto, Andri. (2015). Pengantar Manajemen (3 IN 1), Yogyakarta.

Gunawan, S. N. D. d. L. (2018). "Pengaruh Gaya Kepemimpin Demokratis Terhadap Kinerja Karyawan," Jurnal Manajemen dan Start-Up Bisnis, vol. 3, p. 403.

Jackson, T. a. (2018). Manajemen Pengembangan Sumber Daya Manusia, Bandung.

KANAL, I. (2016). "Kanal Informasi," Lentera Kecil Grup, 19 Oktober. [Online].

Khairunisa, B. N. "Produktivitas Kerja Karyawan Ditinjau Dari Motivasi, Disiplindan dan Lingkungan kerja Pada PT. Iskandar Indah Printing," Edunomika, vol.2,20

Krisnandy, E. N. D. H. (2018). "Pengaruhg Gaya Kepemimpinan Demokratis, Motivasi Intrinsik Dan Disiplin Kerja Terhadap Kinerja Karyawan PT Pangansari Utama Food Industry," Jurnal Ilmu Manajemen, vol. 14, p. 19.

Purba, K., and Sudibjo, K. (2020). The Effects Analysis of Transformational Leadership, Work Motivation and Compensation on Employee Performance in PT. Sago Nauli. Budapest International Research and Critics Institute-Journal (BIRCI-Journal). P. 16061617.

Sahid, S. (2017). "Pengaruh Semangat Kerja dan Disiplin Kerja Terhadap Produktivitas Kerja Karyawan Pada PT. Midi Utama Indonesia, Tbk," Ilmiah, vol. 2.

Setiawan, K. A. (2016). "Pengaruh Gaya Kepemimpinan Dan Kompensasi Terhadap Kinerja Karyawan PT. Astra Honda Nusa Dua Kabupaten Bandung," E-Jurnal Manajemen Unud, Vols. 5, No. 12, p. 7956.

Simamora. (2007). "Pengaruh Motivasi Kerja Dan Gaya Kepemimpinan Terhadap Kinerja Penghulu," SL. Triyaningsih, vol. 2, p. 47.

Siswanto, R. D. (2017). "Pengaruh Gaya Kepemimpinan Terhadap Kinerja Karyawan (Studi Pada Karyawan Divisi Human Resources Management Compensation and Benefits PT Freeport Indonesia)," Jurnal Administrasi Bisnis (JAB), vol. 42, p. 189.

Sudriamunawar. (2017). "Pengaruh Gaya Kepemimpinan Demokratis Terhadap Motivasi Kerja Karyawan Pada PT XYZ," Dinda Ayuandita Nanda dan Rinandita Wikansari, vol. 2, p. 32.

Sugiyono, P. D. (2016). Metode Penelitian, Bandung.

Sutrisno, Edy (2019). Manajemen Sumber Daya Manusia, Surabaya.

Tampi, B. J. (2014). "Pengaruh Gaya Kepemimpinan Dan Motivasi Terhadap Kinerja Karyawan Pada PT. Bank Negara Indonesia , TBK (Regional Sales Manado)," Jurnal Acta Diuma, vol. 3, p. 1.

Yulk. (2017). Modul Kepemimpinan, Medan. 